\title{
FAKTOR - FAKTOR YANG BERHUBUNGAN DENGAN PERILAKU IBU DALAM PEMBERIAN ASI EKSLUSIF DI KLINIK RB BD. SUNDARI TAHUN 2017
}

\author{
Sri Susanti, Ika Apriyanti * \\ Email : srisusanti80@gmail.com ikaaprie88@gmail.com
}

\begin{abstract}
Abstrak
Capaian ASI eksklusif di Indonesia belum mencapai angka yang diharapkan yaitu sebesar 80\%. Berdasarkan laporan SDKI tahun 2012 pencapaian ASI eksklusif adalah 42\%. Sedangkan, berdasarkan laporan dari Dinas Kesehatan Provinsi tahun 2013, cakupan pemberian ASI 0-6 bulan hanyalah 54,3\% (Pusdatin, 2015). Salah satu faktor yang mempengaruhi rendahnya pemberian ASI Eksklusif di Indonesia adalah belum semua tempat kerja menyediakan ruang ASI, budaya memberikan makanan prelaktal, memberikan tambahan susu formula karena ASI tidak keluar, menghentikan pemberian ASI karena bayi atau ibu sakit, ibu harus bekerja, serta ibu ingin mencoba susu formula. Dari hasil studi pendahuluan yang dilakukan oleh peneliti terhadap $10 \mathrm{ibu}$ yang memiliki bayi, 6 orang yang tidak memberikan ASI Ekslusif dengan berbagai macam alasan.

Tujuan penelitian ini dilakukan untuk mengetahui faktor-faktor yang berhubungan dengan perilaku pemberian ASI Ekslusif di Klinik RB Bd. Sundari Tahun 2017.

Metode Penelitian ini menggunakan pendekatan Cross Sectional dengan menggunakan teknik Accidental Sampling dan yang digunakan data primer serta metode pengumpulan data adalah dengan menyebarkan Questionare pada responden Selanjutnya akan dibagikan kepada ibu yang memiliki bayi 6-9 bulan yang melakukan kunjungan di RB bidan sundari. dengan jumlah sampel 88 responden. Uji statistik menggunakan uji Chi Square.

Hasil penelitian analisa univariat didapatkan masi ditemukan responden yang tidak memberikan ASI Ekslusif sebesar 10,2\%. Sedangkan hasil analisa bivariatnya terdapat hubungan yang bermakna antara pengetahuan $(0,04)$ dan dukungan tenaga kesehatan $(0,03)$ dengan perilaaku ibu dalampemberian asi ekslusif di RB sundari tahun 2017. Dan tidak terdapat hubungan yang bermakna anatara kesiapaan saat hamil $(1,00)$ dan dukungan keluarga dengan $\mathrm{p}$ value $(1,00)$.

Diharapkan Masih perlunya meningkatkan upaya promosi kesehatan terutama mengenai pemberian ASI eksklusif secara intensif melalui komunikasi langsung baik pada ibu hamil dan menyusui dengan melibatkan suami, keluarga, tokoh masyarakat,perawat dan bidan tentang pentingnya pemberian ASI.
\end{abstract}

Kata Kunci : Dukungan Keluarga, Dukungan Tenaga Kesehatan, Kesiapan Selama

Kehamilan, Pengetahuan, Perilaku Pemberian ASI Ekslusif

*DosenAkademi Kebidanan `Aisyiyah Banten 


\section{Pendahuluan}

Pemerintah telah menetapkan target cakupan pemberian ASI Eksklusif pada tahun 2010 pada bayi 0-6 bulan sebesar 80\% (Depkes, 2007; Minarto, 2011) sehingga berbagai kebijakan dibuat pemerintah untuk mencapai kesehatan yang optimal yaitu Keputusan Menteri Kesehatan (Kemenkes) Nomor 237 tahun 1997 tentang pemasaran Pengganti Air Susu Ibu dan Kepmenkes No. 450/2004 tentang Pemberian Air Susu Ibu secara ekslusif pada Bayi di Indonesia.

Inisiasi Menyusui Dini dalam 30 menit pertama kelahiran merupakan salah satu dari 10 langkah menuju keberhasilan menyusui yang berdasarkan Inisiatif Rumah Sakit Sayang Bayi (Baby Friendly Hospital Initiative (BFHI)) tahun 1992. Di dalam langkah keempat tertulis "bantu ibu mulai menyusui dalam 30 menit setelah bayi lahir" yaitu dengan metode breast crawl dimana setelah bayi lahir lalu didekatkan di perut ibu dan dibiarkan merangkak untuk mencari sendiri puting ibunya dan akhirnya menghisapnya tanpa bantuan (Yohmi, 2009; Katherine et al, 2005).Setelah melakukan IMD dilanjutkan dengan pemberian ASI Ekslusif selama 6 bulan.

Capaian ASI eksklusif di Indonesia belum mencapai angka yang diharapkan yaitu sebesar $80 \%$. Berdasarkan laporan SDKI tahun 2012 pencapaian ASI eksklusif adalah 42\%. Sedangkan, berdasarkan laporan dari Dinas Kesehatan provinsi tahun 2013, cakupan pemberian ASI 0-6 bulan hanyalah 54,3\% (Pusdatin, 2015). Salah satu faktor yang mempengaruhi rendahnya pemberian ASI Eksklusif di Indonesia adalah belum semua tempat kerja menyediakan ruang ASI. Data pencapaian pemberian ASI Eksklusif untuk tingkat Propinsi Banten tahun 2012 sebanyak $26.04 \%$, data di kota Cilegon tahun 2011 sebanyak 14.8\% , (Profil Dinkes Cilegon 2011).

Dari hasil studi pendahuluan yang dilakukan oleh peneliti terhadap $10 \mathrm{ibu}$ yang memiliki bayi, 6 orang yang tidak memberikan ASI Ekslusif dengan berbagai macam alasan.

Dari uraian diatas menunjukan bahwa cakupan pemberian ASI Eksklusif masih cukup rendah dari (target 80\%), oleh karena itu peneliti sangat tertarik untuk mengambil penelitian tentang asi eksklusif, mengingat betapa pentingnya ASI Eksklusif untuk ibu maupun bayinya.

\section{Metode}

Metode yang digunakan berupa survey dan pendekatan cross sectional dimana variabel bebas dan variabel terikat yang terjadi pada obyek penelitian, di observasi dan di ukur. ). Populasi penelitian ini adalah 726 yaitu seluruh ibu yang memiliki bayi > 6-9 bulan yang 
berkunjung ke RB bidan sundari pada bulan Januari -Juni 2017. Dengan jumlah 88 responden yaitu ibu yang memiliki bayi usia > 6 - 9 bulan. Tekhnik pengambilan sampel dalam penelitian ini adalah menggunakan tekhnik Accidental sampling, metode pengumpulan data menggunakan kuesioner.

\section{Hasil}

Tabel 1

Distribusi Frekuensi responden berdasarkan Perilaku pemberian ASI Eksklusif di RB bd. Sundari tahun 2017

\begin{tabular}{lcc}
\hline $\begin{array}{l}\text { Perilaku } \\
\text { pemberian asi }\end{array}$ & Frekuensi & $\begin{array}{l}\text { Persentase } \\
(\%)\end{array}$ \\
\hline Tdk Ekslusif & 9 & $10.2 \%$ \\
Asi ekslusif & 79 & $89.8 \%$ \\
\hline Total & 88 & $100 \%$ \\
\hline
\end{tabular}

Berdasarkan tabel 1 masih ditemukan perilaku ibu yang tidak memberikan ASI secara ekslusif sebesar 10,2\%

Tabel 2

Distribusi Frekuensi responden berdasarkan pengetahuan di RB bd. Sundari tahun 2017

\begin{tabular}{lcc}
\hline Pengetahuan & Jumlah & Persentase (\%) \\
\hline Rendah & 37 & $42 . \%$ \\
Tinggi & 51 & $58 . \%$ \\
\hline \multicolumn{1}{c}{ Total } & 88 & 100.0 \\
\hline
\end{tabular}

Berdasarkan tabel 2 menunjukan bahwa hampir setengah dari responden memiliki pengetahuan yang kurang mengenai ASI sebesar $42 \%$

Tabel 3

Distribusi Frekuensi responden berdasarkan kesiapan saat hamil di RB bd. Sundari tahun 2017

\begin{tabular}{lcc}
\hline $\begin{array}{l}\text { Kesiapan } \\
\text { saat hamil }\end{array}$ & Jumlah & $(\%)$ \\
\hline Tidak siap & 9 & $10.2 \%$ \\
Siap & 79 & $89.8 \%$ \\
\hline Total & 88 & $100 \%$ \\
\hline
\end{tabular}

Berdasarkan tabel 3 menunjukan bahwa masih ditemukan $(10,2 \%)$ ibu hamil memiliki kesiapan dengan katogori tidak siap dalam upaya yang dilakukan mendukung terhadap usaha keberhasilan menyusui selama kehamilan

Tabel 4

Distribusi Frekuensi responden berdasarkan dukungan keluarga di RB bd. Sundari tahun 2017

\begin{tabular}{lrc}
\hline Dukungan keluarga & Jumlah & $(\%)$ \\
\hline Tidak mendukung & 14 & $15.9 \%$ \\
Mendukung & 74 & $84.1 \%$ \\
\hline Total & 88 & $100 . \%$ \\
\hline
\end{tabular}

Berdasarkan tabel 4 menunjukan bahwa masih ditemukan (15,9\%) responden yang tidak mendapatkan dukungan dari keluarga dalam hal pemberian ASI eksklusif.

Tabel 5

Distribusi Frekuensi responden berdasarkan dukungan tenaga kesehatan di RB bd. Sundari tahun 2017

\begin{tabular}{lcc}
\hline Dukungan tenakes & Jumlah & $(\%)$ \\
\hline Tidak mendukung & 27 & $30.7 \%$ \\
Mendukung & 61 & 69.3 \\
\hline Total & 88 & $100 . \%$ \\
\hline
\end{tabular}


Berdasarkan tabel 5 menunjukan bahwa masih ditemukan (30,7\%) responden yang tidak mendapatkan dukungan dari tenaga kesehatan dalam hal pemberian ASI eksklusif.

Tabel 6

Hubungan Antara Pengetahuan Ibu tentang ASI dengan Perilaku pemberian ASI ekslusif di RB bd. Sundari tahun 2017
Tabel 7

Hubungan Antara Kesiapan ibu saat hamil dengan Perilaku pemberian ASI di RB bd. Sundari tahun 2017

\begin{tabular}{|c|c|c|c|c|c|c|c|}
\hline \multirow{3}{*}{$\begin{array}{c}\text { Kesiapan } \\
\text { saat hamil }\end{array}$} & \multicolumn{4}{|c|}{ Perilaku pemberian ASI } & \multirow{2}{*}{\multicolumn{2}{|c|}{ Jumlah }} & $P$ \\
\hline & \multicolumn{2}{|c|}{$\begin{array}{c}\text { Tidak } \\
\text { Ekslusif }\end{array}$} & \multicolumn{2}{|c|}{ Asi Ekslusif } & & & Value \\
\hline & $\mathbf{N}$ & $\%$ & $\mathbf{N}$ & $\%$ & $\mathbf{N}$ & $\%$ & \\
\hline $\begin{array}{l}\text { Tidak } \\
\text { memiliki } \\
\text { kesiapan }\end{array}$ & 1 & $11.1 \%$ & 8 & $\begin{array}{c}88.9 \\
\%\end{array}$ & 9 & $100 \%$ & 1.000 \\
\hline $\begin{array}{l}\text { Memiliki } \\
\text { kesiapan }\end{array}$ & 10 & $12.7 \%$ & 69 & $\begin{array}{c}87.3 \\
\%\end{array}$ & 79 & $100 \%$ & \\
\hline Total & 11 & $12.5 \%$ & 77 & $\begin{array}{c}87.5 \\
\%\end{array}$ & 88 & $100 \%$ & \\
\hline
\end{tabular}

\begin{tabular}{|c|c|c|c|c|c|c|c|c|}
\hline \multirow{3}{*}{$\begin{array}{l}\text { Penge } \\
\text { tahuan }\end{array}$} & \multicolumn{4}{|c|}{ Perilaku pemberian ASI } & \multirow{2}{*}{\multicolumn{2}{|c|}{ Jumlah }} & \multirow{3}{*}{$\begin{array}{c}P \\
\text { Value }\end{array}$} & \multirow[t]{2}{*}{$O R$} \\
\hline & \multicolumn{2}{|c|}{$\begin{array}{c}\text { Tidak } \\
\text { Ekslusif }\end{array}$} & \multicolumn{2}{|c|}{ Asi Ekslusif } & & & & \\
\hline & $\mathrm{N}$ & $\%$ & $\mathrm{~N}$ & $\%$ & $\mathrm{~N}$ & $\%$ & & \\
\hline Rendah & 8 & $21,6 \%$ & 29 & $78,4 \%$ & 37 & $100 \%$ & 0.04 & 4.414 \\
\hline Tinggi & 3 & $5,9 \%$ & 48 & $94,1 \%$ & 51 & $100 \%$ & & \\
\hline Total & 11 & $12.5 \%$ & 77 & $87.5 \%$ & 88 & $100 \%$ & & \\
\hline
\end{tabular}

Berdasarkan tabel 6 menunjukan bahwa responden yang memiliki pengetahuan rendah memiliki proporsi lebih tinggi untuk tidak memberikan asi eksklusif sebesar (21,6\%) dibanding pada responden yang memiliki pengetahuan tinggi sebesar $(5,9 \%)$.

Hasil uji statistik diperoleh $\mathrm{P}$ value 0.04 dengan tingkat kepercayaan 95\% maka dapat disimpulkan bahwa ada hubungan antara pengetahuan dengan perilaku pemberian asi eksklusif, dengan OR sebesar 4,4 yang artinya responden dengan pengetahuan rendah memiliki resiko untuk tidak memberikan asi eksklusif sebesar 4,4 kali dibandingkan dengan responden yang memiliki pengetahuan tinggi
Berdasarkan tabel 7 menunjukan bahwa responden yang tidak memiliki kesiapan saat hamil proporsinya hampir sama $(11,1 \%)$ dengan responden yang memiliki kesiapan saat kehamilan $(12,7 \%)$ dalam hal tidak memberikan asi eksklusif .

Hasil uji statistik diperoleh $\mathrm{P}$ value 1.000 dengan tingkat kepercayaan 95\% maka dapat disimpulkan bahwa tidak ada hubungan antara kesiapan responden saat hamil dengan perilaku pemberian asi eksklusif

Tabel 8

Hubungan Antara Dukungan keluarga dengan Perilaku pemberian ASI di RB bd. Sundari tahun 2017

\begin{tabular}{|c|c|c|c|c|c|c|c|}
\hline \multirow{3}{*}{$\begin{array}{c}\text { Dukungan } \\
\text { keluarga }\end{array}$} & \multicolumn{4}{|c|}{$\begin{array}{c}\text { Perilaku pemberian } \\
\text { ASI }\end{array}$} & \multirow{2}{*}{\multicolumn{2}{|c|}{ Jumlah }} & \multirow[t]{3}{*}{$\begin{array}{c}P \\
\text { Value }\end{array}$} \\
\hline & \multicolumn{2}{|c|}{$\begin{array}{c}\text { Tidak } \\
\text { Ekslusif } \\
\end{array}$} & \multicolumn{2}{|c|}{$\begin{array}{c}\text { Asi } \\
\text { Ekslusif }\end{array}$} & & & \\
\hline & $\mathrm{N}$ & $\%$ & $\mathrm{~N}$ & $\%$ & $\mathrm{~N}$ & $\%$ & \\
\hline $\begin{array}{l}\text { Tidak } \\
\text { mendukung }\end{array}$ & 1 & $7.1 \%$ & 13 & $\begin{array}{c}92.9 \\
\%\end{array}$ & 14 & $\begin{array}{c}100 \\
\%\end{array}$ & 1.000 \\
\hline Mendukung & 10 & $13.5 \%$ & 64 & $\begin{array}{c}86.5 \\
\%\end{array}$ & 74 & $\begin{array}{l}100 \\
\%\end{array}$ & \\
\hline Total & 11 & $12.5 \%$ & 77 & $\begin{array}{c}87.5 \\
\%\end{array}$ & 88 & $\begin{array}{l}100 \\
\%\end{array}$ & \\
\hline
\end{tabular}


Berdasarkan tabel 8 menunjukan bahwa responden yang tidak mendapat dukungan dari keluarga memiliki proporsi lebih kecil untuk tidak memberikan ASI ekslusif sebesar $(7,1 \%)$ dibanding pada responden yang mendapatkan dukungan dari keluarga sebesar $(13,5 \%)$.

Hasil uji statistik diperoleh $\mathrm{P}$ value 1.000 dengan tingkat kepercayaan 95\% maka dapat disimpulkan bahwa tidak ada hubungan antara dukungan keluarga dengan perilaku pemberian asi eksklusif

Tabel 9

Hubungan Antara dukungan tenaga kesehatan dengan Perilaku pemberian ASI di RB bd. Sundari tahun 2017

\begin{tabular}{|c|c|c|c|c|c|c|c|c|}
\hline \multirow{3}{*}{$\begin{array}{l}\text { Dukungan } \\
\text { tenaga } \\
\text { kesehatan }\end{array}$} & \multicolumn{4}{|c|}{$\begin{array}{c}\text { Perilaku pemberian } \\
\text { ASI } \\
\end{array}$} & \multirow{2}{*}{\multicolumn{2}{|c|}{ Jumlah }} & \multirow{3}{*}{$\begin{array}{c}P \\
\text { Val } \\
\text { ue }\end{array}$} & \multirow[t]{3}{*}{ OR } \\
\hline & \multicolumn{2}{|c|}{$\begin{array}{c}\text { Tidak } \\
\text { Ekslusif }\end{array}$} & \multicolumn{2}{|c|}{ Asi Ekslusif } & & & & \\
\hline & $\mathrm{N}$ & $\%$ & $\mathrm{~N}$ & $\%$ & $\mathrm{~N}$ & $\%$ & & \\
\hline $\begin{array}{l}\text { Tidak } \\
\text { mendukung }\end{array}$ & 7 & $25.9 \%$ & 20 & $74.1 \%$ & 27 & $100 \%$ & 0.030 & 4.988 \\
\hline Mendukung & 4 & $6.6 \%$ & 57 & $93.4 \%$ & 61 & $100 \%$ & & \\
\hline Total & 11 & $12.5 \%$ & 77 & $87.5 \%$ & 88 & $100 \%$ & & \\
\hline
\end{tabular}

Berdasarkan tabel 9 menunjukan bahwa responden yang tidak mendapat dukungan dari tenaga kesehatan memiliki proporsi lebih tinggi untuk tidak memberika asi eksklusif sebesar $(25,9 \%)$ dibanding pada responden yang mendapatkan dukungan dari tenaga kesehatan sebesar (6.6\%).

Hasil uji statistik diperoleh $\mathrm{P}$ value 0.030 dengan tingkat kepercayaan 95\% maka dapat disimpulkan bahwa ada hubungan antara dukungan tenaga kesehatan dengan perilaku pemberian asi eksklusif. dengan OR sebesar 4,9 artinya responden yang tidak mendapatkan dukungan dari petugas kesehatan memiliki peluang untuk tidak memberikan asi ekslusif sebesar 4,9 kali dibanding responden yang mendapatkan dukungan.

\section{Pembahasan}

\section{Pengetahuan Ibu tentang ASI dengan Perilaku pemberian}

Secara umum penelitian ini sejalan dengan teori dari Notoatmodjo (2005). bahwa pegetahuan merupakan hasil dari tahu, dan ini terjadi setelah orang melakukan penginderaan terhadap satu objek tertentu. Secara khusus penelitian ini sejalan Roesli (2004), yang mengungkapkan bahwa fenomena kurangnya pemberian ASI eksklusif disebabkan oleh beberapa faktor, diantaranya : pengetahuan ibu yang kurang memadai tentang ASI eksklusif, beredarnya mitos yang kurang baik tentang pemberian ASI eksklusif, serta kesibukan ibu dalam melakukan pekerjaanya dan singkatnya pemberian cuti melahirkan yang diberikan oleh pemerintah terhadap ibu yang bekerja, merupakan alasan-alasan yang sering diungkapkan oleh ibu yang tidak berhasil menyusui secara ekslusif.

ASI memiliki semua unsur-unsur yang memenuhi kebutuhan bayi akan gizi selama periode sekitar 6 bulan, kecuali jika 
ibu megalami keadaan gizi kurang yang berat atau gangguan kesehatan lain.

\section{Kesiapan saat hamil dengan Perilaku pemberian ASI ekslusif}

Menurut parwati (2007) Persiapan menyusui pada masa kehamilan merupakan hal yang penting dilakukan, sebab dengan persiapan yang lebih baik maka ibu lebih siap menyusui bayinya dan menunjang keberhasilan ASI eksklusif.

Namun hasil penelitian yang dilakukan di RB bidan sundari tidak sejalan dengan pernyataan diatas, hasil pengolahan data di dapatkan baik ibu yang melakukan persiapan saat hamil maupun tidak memiliki persiapan saat hamil, memiliki prosentase yang hampir sama untuk perilku pemberian asi eksklusif, hal ini dapat dilihat dari pengetahuan responden di RB bidan sundari bahwa lebih dari setengah responden memiliki pengetahuan yang tinggi, sehingga walaupun ibu tidak memiliki kesiapan saat hamil tetapi responden memiliki tingkat pengetahuan yang baik.

\section{Dukungan keluarga dengan Perilaku pemberian ASI ekslusif}

Dukungan keluarga adalah dukungan untuk memotivasi ibu memberikan ASI saja kepada bayinya sampai usia 6 bulan. Dukungan atau support dari orang lain atau orang terdekat, sangat berperan dalam sukses tidaknya menyusui. Semakin besar dukungan yang didapatkan untuk terus menyusui maka akan semakin besar pula kemampuan untuk dapat bertahan terus untuk menyusui. Dukungan suami maupun keluarga sangat besar pengaruhnya, seorang ibu yang kurang mendapatkan dukungan oleh suami, ibu, adik atau bahkan ditakut-takuti, dipengaruhi untuk beralih ke susu formula (Proverawati, 2010)

Penelitian yang dilakukan oleh Rokhanawati, Dewi (2009) Proporsi dukungan sosial suami rendah 3,02 lebih besar pada kelompok perilaku pemberian ASI tidak eksklusif dibandingkan dengan kelompok perilaku pemberian ASI eksklusif.

Hasil dari penelitian yang telah dilakukan penulis didapatkan hasil tidak ada hubungan antara dukungan keluarga dengan pemberian asi ekslusif. justru dalam penelitian ini katagori responden yang tidak mendapat dukungan dari keluarga memiliki proporsi lebih kecil untuk tidak memberikan ASI ekslusif sebesar $(7,1 \%)$ dibanding pada responden yang mendapatkan dukungan dari keluarga sebesar $(13,5 \%)$.

Dukungan tenaga kesehatan dengan Perilaku pemberian ASI ekslusif

Dukungan tenaga kesehatan mempengaruhi ibu dalam memberikan ASI 
eksklusif karena dukungan merupakan upaya yang dilakukan oleh tenaga kesehatan dalam membentuk perilaku ibu untuk memberikan ASI eksklusif. Ibu yang mendapatkan dukungan dari tenaga kesehatan lebih cenderung memberikan ASI eksklusif dibandingkan yang tidak mendapatkan dukungan dari tenaga kesehatan Semakin dukungan baik, cakupan ASI eksklusif akan semakin tinggi.

Penelitian ini juga sejalan dengan Penelitian yang dilakukan (Ariwati dkk, 2014) merupakan penelitian survey analitik dengan rancangan penelitian cross sectional dengan jumlah populasi $308 \mathrm{ibu}$ dan jumlah sampel $76 \mathrm{ibu}$ menyusui yang mempunyai bayi usia $<6$ bulan. Hasil uji chi square dengan SPSS menunjukkan nilai $\mathrm{p}$ adalah 0,0001 yang artinya ada hubungan signifikan antara dukungan bidan tentang ASI eksklusif dengan perilaku pemberian ASI eksklusif di wilayah kerja Puskesmas Ambarawa Kabupaten Semarang dan nilai $\mathrm{PR}=2,48$, artinya ibu yang mendapat dukungan dari bidan mempunyai peluang 2,48 kali lipat lebih besar untuk menyusui secara eksklusif dibandingkan ibu yang kurang mendapatkan dukungan dari bidan.

Dukungan tenaga kesehatan terhadap pemberian ASI eksklusif ini sangat penting tidak hanya bagi bayi tetapi juga bagi ibu menyusui. Dukungan dalam pemberian ASI akan mempengaruhi perilaku dalam pemberian ASI karena dukungan merupakan faktor yang mempengaruhi tindakan kesehatan individu, kelompok, atau masyarakat.

\section{Simpulan}

Berdasarkan hasil penelitian, ada hubungan antara pengetahuan dan dukungan tenaga kesehatan dengan perilaku pemberian asi ekslusif di RB Bidan Sundari cilegon tahun 2017 dan tidak ada hubungan antara persiapan saat hamil dan dukungan keluarga dengan perilaku pemberian ASI Ekslusif di RB Sundari Tahun 2017

\section{Daftar Pustaka}

Aprilia, Y. 2009. Analisis Sosialisasi Program Inisiasi Menyusu Dini Dan Asi Eksklusif Kepada Bidan Di Kabupaten Klaten. Tesis Universitas Diponegoro Semarang. Arikunto, S. 2006. Prosedur Penelitian Suatu Pendekatan Praktek. Cetakan ke II. Edisi Revisi IV. Jakarta: PT. Rineka Cipta.

Asosiasi Ibu Menyusui Indonesia(AIMI). (2013). Tenaga Kesehatan Indonesia Perlu Sosialisasi Kebijakan Menyusui. Diakses pada tanggal 16 November, 2016, dari http://aimiasi.org/tenaga-kesehatanindonesiaperlu-sosialisasikebijakan-menyusui/

Azwar S. 2005. Sikap Manusia Teori dan Pengukurannya. Yogyakarta: Pustaka Pelajar. 
Depkes RI. 2003. Warta Kesehatan Masyarakat. Jakarta: Departemen Kesehatan RI.

Gunarsa \& Gunarsa. (1995). Psikologi Praktis : anak, remaja, dan keluarga.

Gunarsa, Singgih D. 2003. Psikologi Untuk Keluarga. Jakarta: Gunung Mulia

Gunarsa, Singgih D. 2006. Dari Anak Sampai Usia Lanjut : Bunga Rampai Psikologi Perkembangan. Jakarta : PT BPK Gunung Mulia

Hapsari. 2009. Manajemen laktasi. Agustus 28, 2014. http://superbidanhapsari.wordpress.c om/2009/12/14

Haryono dan Setianingsih. 2014. Manfaat ASI eksklusif untuk buah hati anda. Yogyakarta: Gosyen Publishing

Minarto, 2011. Rencana aksi pembinaan gizi masyarakat tahun 2010-2014. Online (www.gizikia.depkes.go.id, diakses 18 Februari 2012)

Monica, 2010. Peran Keluarga Dalam Pemberian Asi Ekslusif di Kabupaten Jeneponto

Muchtadi, Deddy. 1996. Gizi untuk Bayi: ASI, Susu Formula dan Makanan Tambahan. Jakarta: Pustaka Sinar Harapan.

Nelson, Joan. 2001. Cara Menyusui yang Baik. Jakarta: Penerbit Arcan.

Notoatmodjo, Soekidjo. 2003. Ilmu Kesehatan Masyarakat. Jakarta: Penerbit Rineka Cipta. 2010. Promosi Kesehatan Teori dan Aplikasi. Jakarta: Rineka Cipta.

Nursalam, Konsep dan Penerapan Metodologi Penelitian Ilmu Keperawatan, Jakarta : Salemba medika., 2008

Padmawati, IA. 2013. Manajemen laktasi. Jakarta

Rinata, Evi. 2015. Persiapan Asi Ekslusif Ibu Hamil di RB Eva Candi Sidoardjo. Midwiferia / Vol. 1 ; No. 2 / Oktober 2015
Roesli, U. 2005. Mengenal ASI Ekslusif. Jakarta : PT Pustaka Pembangunan Swadaya Nusatara

Roesli, Utami. 2000. Mengenal ASI Eksklusif. Jakarta: PT Elex Komputindo.

Roesli, Utami. 2001. Bayi Sehat Berkat ASI Eksklusif, Makanan Pendamping Tepat dan Imunisasi Lengkap, Jakarta: PT Elek Media Komputindo.

Santoso, A. 2009. Faktor-Faktor yang Memengaruhi Pemberian Asi Eksklusif pada Rumah Tangga Miskin di Provinsi Sulawesi Tengah dengan Pendekatan MARS Bagging. [Tesis tidak dipublikasikan]. Surabaya: Program Pasca Sarjana Jurusan Statistika ITS.

Soetjiningsih. 1997. ASI Petunjuk Untuk Tenaga Kesehatan, Jakarta: Buku Kedokteran EGC.

Sugiono. 2012. Statistik untuk Penelitian. Cetakan kedua. Bandung: Penerbit,CV.Alfabeta.

Suharyono, Suradi dan Rulina. 2002. ASI Tinjauan dari Beberapa Aspek. Jakarta: Fakultas Kedokteran Universitas Indonesia.

Suraji, R. 2003. Manajemen Laktasi. Program Manajemen Laktasi. Perkumpulan Perinatologi di RSU Tapak Tuan, Aceh.

Widiyani, Rosmha. (2013). Lima Puluh Persen Tenaga Kesehatan Tidak Tahu PP ASI Ekslusif. Diakses pada tanggal 16 November 2016, dari http://health.kompas.com/read/2013/ 06/13/2005344/50.Persen.Tenaga.K esehatan.Tak.Tahu.PP.ASI.Eksklusi f.

World Health Organization (WHO). 2003. Community-Based strategies for Breastfeeding Promotion and Support in Developing Countries.

Yohmi, E. 2009. Inisiasi menyusu dini. Ikatan Dokter Anak Indonesia. Online (www. Idai.or.id, diakses 18 Februari 2012) 